\title{
Określanie składu chemicznego i mineralnego skał z wykorzystaniem przenośnego spektrometru XRF pracującego w atmosferze helu
}

\section{Determination of the chemical and mineral composition of rocks with the use of a portable XRF spectrometer operating in a helium atmosphere}

\author{
Rafał Skupio \\ Instytut Nafty i Gazu - Państwowy Instytut Badawczy
}

\begin{abstract}
STRESZCZENIE: W pracy przedstawiono możliwości prowadzenia pomiarów chemicznych z zastosowaniem przenośnego spektrometru fluorescencji rentgenowskiej z dyspersją energii EDXRF w atmosferze helu. Metodyka badawcza wraz z tworzeniem modeli i interpretacją danych powstała w oparciu o zastosowanie aparatu XRF firmy Bruker, model Tracer 5g. Prowadzenie pomiarów w atmosferze helu umożliwia obniżenie progów detekcji dla pierwiastków lekkich, w tym określanie udziałów sodu (Na) i magnezu (Mg) oraz pierwiastków wchodzących w zakres spektrometrycznego profilowania gamma: potasu (K), uranu (U) i toru (Th). Jednym z elementów nowej procedury pomiarowej jest przygotowanie preparatów w formie pastylek, przy użyciu prasy hydraulicznej o sile nacisku do 25 ton. Pomiary w atmosferze helu mogą być wykonywane jedynie na materiale skonsolidowanym (lita skała, rdzeń wiertniczy lub twarda pastylka). Materiał do badań został pobrany z rdzeni wiertniczych, następnie skwartowany i rozdzielony na poszczególne analizy. Wyniki analiz XRF uzyskane metodą, w której zastosowano przepływ helu, porównano z wynikami pomiarów wykonanych standardową aparaturą XRF, chemicznych badań laboratoryjnych, analiz składu mineralnego XRD oraz badań naturalnej promieniotwórczości gamma. Analizy XRF bez możliwości prowadzenia pomiarów w atmosferze helu wykonane zostały aparatem Titan S1 (firmy Bruker). Badania przeprowadzono na próbkach skał pochodzących z dwóch otworów wiertniczych - P4 (19 próbek) i J1 (11 próbek). W przypadku P4 dysponowano dokładnymi pomiarami laboratoryjnymi ICP-MS (ang. Inductively Coupled Plasma Mass Spectrometry), ICP-OES (ang. Inductively Coupled Plasma Mass Spectrometry) oraz wynikami XRD, natomiast w J1 - wynikami badań radiometrycznych i mineralnych. W próbkach z otworu J1 występowały skalenie oraz dolomit, co umożliwiło przetestowanie budowy modeli uwzględniających te minerały w odniesieniu do wyznaczenia udziałów sodu i magnezu. W końcowej części pracy przedstawiono wykresy korelacyjne dla wybranych, najważniejszych pierwiastków budujących matrycę skalną, modele mineralno-chemiczne zbudowane na ich podstawie oraz wykresy korelacyjne dla spektrometrycznych pomiarów gamma.
\end{abstract}

Słowa kluczowe: spektrometria XRF, litologia, skład chemiczny, skład mineralny, spektrometria gamma, analizy rdzeni wiertniczych.

ABSTRACT: In the paper, author presented the possibility of conducting chemical measurements in a helium atmosphere using a portable Energy Dispersive X-Ray Fluorescence spectrometer (EDXRF). The methodology, model creation and data interpretation were based on the Tracer 5g XRF (Bruker) application. Measurements in a helium atmosphere enable the reduction of detection limits for light elements, including the determination of sodium $(\mathrm{Na})$ and magnesium $(\mathrm{Mg})$, as well as elements applied in the spectral gamma-ray profiling range: potassium $(\mathrm{K})$, uranium $(\mathrm{U})$ and thorium $(\mathrm{Th})$. One of the new measurement procedure aspects is the preparation of pellets using a hydraulic press with a pressure of up to 25 tons. Measurements with helium flow can only be performed on a consolidated material (solid rock, drill core, or pellet). The material for the research was taken from the cores, then quartered and divided into individual analyses. The results of the XRF analyses obtained with the helium flow method were compared to measurements made with standard XRF equipment, chemical laboratory tests, the results of XRD mineral analyses, and tests of natural gamma radioactivity. XRF analyses without the possibility of conducting measurements in a helium atmosphere were performed with the Titan S1 apparatus (Bruker). The tests were carried out on rock samples from two boreholes, P4 (19 samples) and J1 (11 samples). In P4, precise laboratory measurements ICP-MS (Inductively Coupled Plasma Mass Spectrometry), ICP-OES (Inductively Coupled Plasma Optical Emission Spectrometry) and XRD results were available, while in the J1, radiometric and mineral tests were performed. Feldspars and dolomites were present in the samples from the $\mathrm{J} 1$ borehole, which made it possible to test the construction of models incorporating these minerals in relation to sodium and magnesium. The final part of the work presents correlation diagrams for selected, most essential elements forming the rock matrix, mineral and chemical models built on their basis and correlation diagrams for gamma spectrometric measurements.

Key words: XRF spectrometry, lithology, chemical composition, mineral composition, spectral gamma-ray measurements, core analyses.

Autor do korespondencji: R. Skupio, e-mail: rafal.skupio@inig.pl

Artykuł nadesłano do Redakcji: 19.01.2021 r. Zatwierdzono do druku: 07.04.2021 r. 


\section{Wstęp}

Techniki spektrometrii fluorescencji rentgenowskiej znane są od lat 50. ubiegłego wieku, natomiast nowe urządzenia i sposoby ich zastosowania w wielu działach przemysłu są wciąż rozwijane (Acquafredda, 2019). Aparatura przenośna ogranicza się do spektrometrów XRF z dyspersją energii (EDXRF), umożliwiających wykonywanie pomiarów nieinwazyjnych bezpośrednio na rdzeniach wiertniczych lub odsłonięciach skalnych, bez konieczności pobierania próbek (Ogburn et al., 2012; Rowe et al., 2012). Możliwość prowadzenia badań nieinwazyjnych pozwala również na wykonywanie analiz chemicznych dzieł sztuki i obiektów dziedzictwa kulturowego (Chen $i$ in. 2018). Spektrometry EDXRF występują również w formie urządzeń stacjonarnych, natomiast najczęściej stosowane są spektrometry z dyspersją fali WDXRF. Dokładność oraz powtarzalność wyników w przypadku metod wykorzystujących zjawisko fluorescencji jest bardzo wysoka. Techniki pomiarowe różnią się pod względem liczby identyfikowanych pierwiastków oraz wartości ich progów wykrywalności. EDXRF z zastosowaniem helu ma możliwość określenia ilościowego pierwiastków w zakresie od sodu do uranu, natomiast WDXRF - od berylu do uranu, jak również posiada niższe progi detekcji (Jędrychowska i Wieczorek, 2013). Pomiary ilościowe wykonuje się zazwyczaj za pomocą metod empirycznych z wykorzystaniem wzorców do kalibracji aparatury stacjonarnej (Wieczorek, 2012; Conrey et al. 2014). Brak odpowiednich kalibracji, pomimo dokładnych urządzeń analitycznych, nie pozwoli na wiarygodne określanie ilościowego składu pierwiastkowego. Metody ICP-MS (spektrometria mas sprzężona z plazmą wzbudzaną indukcyjnie) i ICP-OES (atomowa spektrometria emisyjna ze wzbudzeniem w plazmie indukowanej) służą do wykonywania pomiarów referencyjnych szerokiego zakresu pierwiastków. Metody te wykorzystywane są do jakościowego i ilościowego określania ponad 70 pierwiastków w szerokim zakresie stężeń (Kozak, 2010). Pomiary chemiczne skał są uzupełnieniem, a zarazem metodą sprawdzającą wyniki interpretacji mineralogicznej XRD. W wielu przypadkach pomagają rozwiązywać problemy mineralogiczne w skałach z analizowanych otworów wiertniczych (Loubser i Verryn, 2008). Korelacje wybranych pierwiastków z odpowiednimi minerałami umożliwiają wykonanie interpretacji litologicznej na podstawie modeli mineralogiczno-chemicznych.

Interpretacja litologiczna skał przewierconych otworem wiertniczym wymaga wykonania serii analiz wzdłuż jego profilu z zadanym krokiem pomiarowym. Badania wykonuje się w celu wydzielenia warstw/stref o odmiennej litologii lub odmiennym środowisku depozycyjnym. W wielu przypadkach nie ma możliwości poboru prób do badań laboratoryjnych, a przenośne spektrometry XRF to jedyne narzędzia umożliwiające wykonywanie nieinwazyjnego profilowania geochemicznego. Badania te pozwalają na szczegółową interpretację litologiczną również na próbkach skał z otworów archiwalnych, w których nie były przeprowadzone pomiary geofizyki otworowej, a pobrano rdzeń (Kowalska et al., 2018). W przypadku pomiarów zwiercin w trakcie wiercenia otworu (ang. real time), możliwe jest kierowanie trajektorią otworu (ang. geosteering) i podejmowanie decyzji na podstawie wyników szczegółowych badań składu chemicznego i mineralnego przewiercanych skał (Chao et al., 2015). Budowa odpowiednich modeli na podstawie identyfikacji pierwiastków śladowych umożliwia dodatkowo szacowanie zailenia oraz całkowitej zawartości węgla organicznego TOC (ang. Total Organic Carbon). Do obliczenia zailenia moga zostać wykorzystane pierwiastki wyznaczane na podstawie spektrometrycznego profilowania gamma: potas (K), uran (U), oraz tor (Th) (Skupio i Dohnalik, 2015; Skupio i Wolański, 2019), jak również glin $\left(\mathrm{Al}_{2} \mathrm{O}_{3}\right)$, będący składnikiem minerałów ilastych. Do szacowania zawartości TOC wykorzystuje się pierwiastki, które dobrze korelują, osiągając wysokie współczynniki determinacji, z laboratoryjnymi oznaczeniami TOC, takie jak molibden (Mo), nikiel (Ni) czy miedź (Cu) (Alnahwi i Loucks, 2019). Na podstawie wyników pomiarów XRF możliwe jest również określanie współczynnika kruchości skał w oparciu o wyznaczone zawartości wybranych minerałów (Yasin et al., 2017). Jarvie i in. (2007) zaproponowali metodę, w której za kruchość odpowiada głównie relacja kwarcu do minerałów ilastych w skałach łupkowych a Wang i Gale (2009) uwzględnili w tej relacji również dolomit.

\section{Metodyka pomiarowa i przygotowanie prób do analiz XRF}

Do wykonania testów wytypowano próbki piaskowców czerwonego spągowca pobrane $\mathrm{z}$ rdzeni archiwalnych. Badane skały pochodziły z dwóch otworów wiertniczych: P4 - 19 próbek i J1 - 11 próbek. W otworze P4 wykonano chemiczne pomiary laboratoryjne oraz badania mineralogiczne XRD, natomiast $\mathrm{w}$ otworze J1 serię laboratoryjnych pomiarów radiometrycznych $(K, U, T h)$ oraz analizy XRD. Stacjonarne badania chemiczne zostały wykonane w laboratorium zewnętrznym metodą: FUS-ICP, składającą się $\mathrm{z}$ analiz ICP-MS, ICP-OES, w której mierzone są preparaty stapiane z zastosowaniem tetraboranu/metaboranu litu. Pomiary te stosowane są do sprawdzenia jakości wyników, jak również do kalibracji aparatury (Skupio et al., 2020).

Badania przeprowadzono z wykorzystaniem dwóch przenośnych spektrometrów fluorescencji rentgenowskiej XRF. 
Pierwszy z nich jest standardowo używany w Zakładzie Geofizyki Wiertniczej Instytutu Nafty i Gazu - Państwowego Instytutu Badawczego w Krakowie od roku 2013 - jest to spektrometr Titan S1 firmy Bruker (Skupio, 2014), (rys. 1a). Nowy aparat Tracer 5g (rys. 1b), którego producentem również jest firma Bruker został zakupiony w roku 2019 (Bruker). Spektrometr Tracer 5g wykorzystuje dyspersję energii EDXRF i nie wymaga stosowania wzorców. Został on wyposażony W anodę Rh (o maksymalnych parametrach: $50 \mathrm{kV}, 200 \mu \mathrm{A}$, $4 \mathrm{~W}$ ) i grafenowy detektor $20 \mathrm{~mm}^{2}$ (ang. Silicon Drift Detector, SDD), o typowej rozdzielczości 140 eV dla linii Mn K-alfa (Skupio, 2020). Oprogramowanie może być dostosowane dla różnych działów przemysłu, co pozwala na wykonywanie bardzo dokładnych pomiarów. Spektrometr jest wyposażony w pakiety kalibracyjne: GeoExplotration, Mudrock, Mudrock He, Limestone oraz Precious Metals, dostosowane do analizy zarówno pierwiastków występujących w skałach o matrycy krzemionkowej lub węglanowej, jak też w stopach metali. Zakres pomiarowy urządzenia przenośnego pozwala na detekcję maksymalnie 49 pierwiastków, od sodu $(\mathrm{Na})$ do uranu (U). Pierwiastki można podzielić na dwie grupy: lekkie oraz ciężkie. W skład pierwiastków lekkich wchodzą: Na, $\mathrm{Mg}, \mathrm{Al}, \mathrm{Si}, \mathrm{P}, \mathrm{S}, \mathrm{Cl}, \mathrm{K}, \mathrm{Ca}$. Sód jest najlżejszy z mierzonych, a zarazem posiada najniższą wartość liczby atomowej, jedyną możliwością detekcji sodu jest analiza w atmosferze helu. Tracer $5 \mathrm{~g}$ jest dostosowany do prowadzenia pomiarów $\mathrm{w}$ atmosferze helu (rys. 1b).

W roku 2014 zaproponowano metodykę przygotowania prób oraz prowadzenia pomiarów z wykorzystaniem spektrometru Titan S1, (Skupio, 2014). Od tego czasu metodyka ta była wielokrotnie modyfikowana w celu osiągania jak najlepszych wyników. Pomiary z wykorzystaniem przenośnych spektrometrów XRF można podzielić na dwa rodzaje: pomiar na preparacie i pomiar na całym rdzeniu wiertniczym. Typ pomiaru określany jest w zależności od dostępnego materiału. W przypadku gdy rdzeń jest w dobrym stanie, ma gładkie powierzchnie, drobne uziarnienie i nie jest mocno porowaty - pomiary mogą być wykonywane z zadowalającą dokładnością bezpośrednio na nim.

W celu wykonania wysokiej jakości interpretacji litologicznej pomiary prowadzone są na próbkach sproszkowanych i sprasowanych. Zakład Geofizyki Wiertniczej INiG PIB w Krakowie dysponuje prasą hydrauliczną o nacisku do 25 ton, co umożliwia wykonywanie preparatów w postaci pastylek, przeznaczonych zarówno do standardowych pomiarów XRF, jak też do pomiarów w atmosferze helu. Dla zilustrowania różnicy $\mathrm{w}$ wyglądzie i strukturze próbki przedstawiono preparaty sprasowane z naciskiem 1 tony (rys. 2a) oraz 20 ton (rys. 2b). Struktura powierzchni pastylki sprasowanej z małym naciskiem jest nierówna i rozsypliwa, w przypadku zwiększenia nacisku, preparaty stają się bardziej trwałe, a ich powierzchnia gładka.

Materiał do badań może być pobierany z rdzeni wiertniczych lub z okruchów uzyskiwanych w trakcie wiercenia otworu. Ilość materiału przeznaczona do pomiarów XRF powinna wynosić około 10 gramów. Próbki z rdzeni zazwyczaj są częścią materiału wytypowanego do standardowych badań laboratoryjnych (np. XRD, radiometria) - są to pomiary punktowe. Możliwe jest również pobieranie prób rdzeniowych w postaci pasa skały odciętego wzdłuż całej długości rdzenia. Metoda ta pozwala na uzyskanie reprezentatywnego i uśrednionego materiału dla interwałów np. 50 cm, co ma szczególne znaczenie

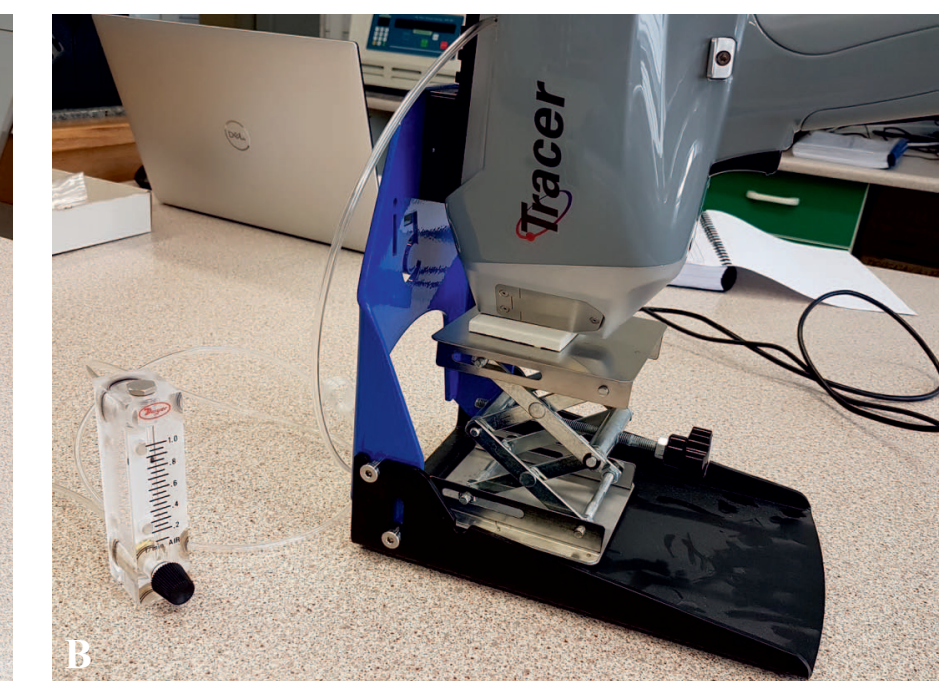

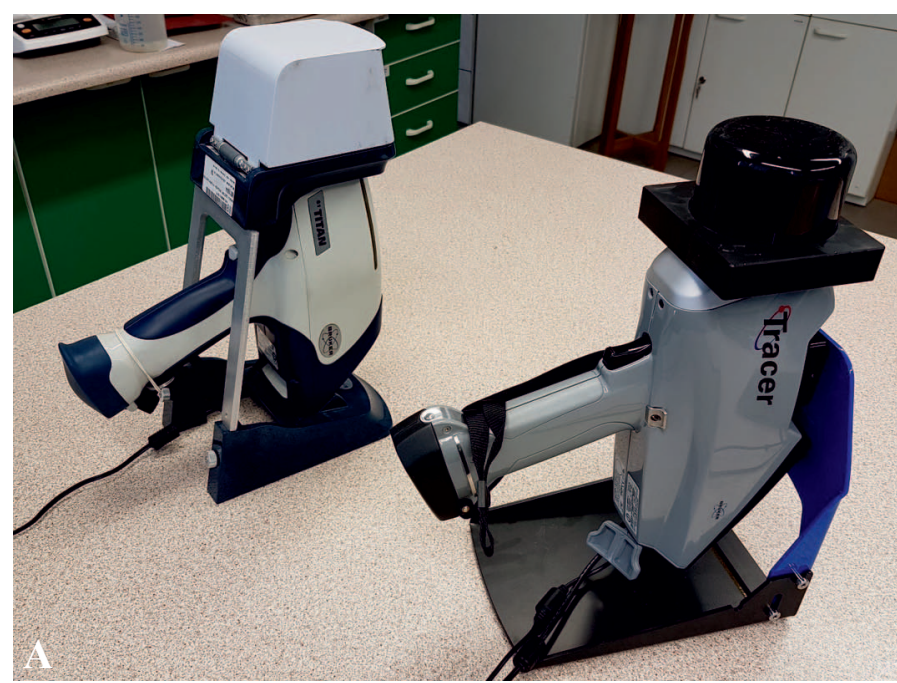

Rys. 1. A) Spektrometry XRF ustawione detektorem ku górze do pomiarów wykonywanych standardowo, z lewej strony spektrometr Titan S1, z prawej Tracer 5g; B) Spektrometr Tracer 5g, ustawiony detektorem ku dołowi, w trybie przygotowanym do pomiarów wykonywanych w atmosferze helu

Fig. 1. A) XRF spectrometers prepared for standard measurements: Titan $\mathrm{S} 1$ on the left side, Tracer $5 \mathrm{~g}$ on the right side; B) Tracer $5 \mathrm{~g}$ spectrometer set to measurement mode with a helium atmosphere 

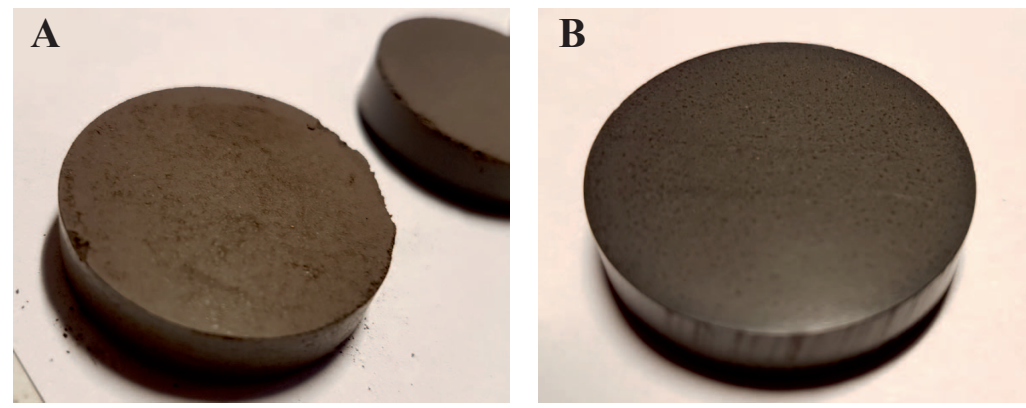

Rys. 2. Pastylka sprasowana naciskiem: A) 1 tony; B) 20 ton

Fig. 2. The tablet made with a pressure of: A) 1 ton; B) 20 tons

w prowadzeniu badań referencyjnych. W przypadku pomiarów na zwiercinach, pobierany materiał musi zostać oczyszczony, wysuszony oraz zmielony do jednorodnej frakcji (mielenie w pojemnikach agatowych). W przypadku zwiercin krok pomiarowy wynosi standardowo $5 \mathrm{~m}$ lub 10 metrów, co odpowiada częstotliwości pobierania próbek.

Pomiary chemiczne XRF dla próbek z otworu P4 wykonano spektrometrem Titan S1 według standardowej procedury polegającej na zmieleniu próbki i umieszczeniu jej w pojemniku $\mathrm{z}$ dnem wykonanym $\mathrm{z}$ folii polipropylenowej o grubości $6 \mu \mathrm{m}$ „Titan” oraz na pastylce sprasowanej w prasie hydraulicznej naciskiem 20 ton „Titan (prasa)”. Dla tych samych próbek wykonano pomiary aparatem Tracer 5g, zarówno na preparatach sproszkowanych „Tracer”, jak i na próbkach sprasowanych „Tracer (prasa)”. Ostatnia seria pomiarowa została przeprowadzona na pastylkach z zastosowaniem spektrometru pracującego $\mathrm{w}$ trybie umożliwiającym przepływ helu „Tracer He”. Czas pomiarowy dla wszystkich analiz został ustawiony na $5 \mathrm{~min}$, a przepływ helu na $0,6 \mathrm{~L} / \mathrm{min}$. Preparaty mielono w młynku planetarnym wyposażonym w pojemniki agatowe, z założonym czasem mielenia $15 \mathrm{~min}$ i $750 \mathrm{obr} / \mathrm{min}$.

\section{Wyniki badań}

Wyniki pomiarów wykonanych dwoma spektrometrami na próbkach sypkich i sprasowanych w odniesieniu do pomiarów laboratoryjnych zestawiono w postaci wykresów korelacyjnych (rys. 3). W celu porównania jakości danych wybrano najważniejsze (lekkie) pierwiastki budujące matrycę skalną i biorace udział w tworzeniu modeli mineralogiczno-chemicznych. Na wykresach przedstawiono korelacje dla $\mathrm{SiO}_{2}$, $\mathrm{CaO}, \mathrm{Al}_{2} \mathrm{O}_{3}, \mathrm{~K}_{2} \mathrm{O}, \mathrm{MgO}, \mathrm{Na}_{2} \mathrm{O}$. Oznaczenie krzemu, będącego głównym składnikiem analizowanych skał, z zastosowaniem standardowej metody preparatyki oraz pomiaru (Titan), osiągnęło współczynniki determinacji na poziomie 0,71 , sprasowanie próbek podniosło współczynnik $\mathrm{R}^{2}$ do 0,89 . Zastosowanie spektrometru Tracer 5g, zarówno dla próbek sproszkowanych, jak i sprasowanych, pozwoliło uzyskać $\mathrm{R}^{2}$ na poziomie
0,82 i 0,85 , natomiast wykonanie pomiarów w atmosferze helu umożliwiło osiągnięcie najwyższego współczynnika, równego 0,92. Analiza zawartości wapnia wykazała bardzo wysokie współczynniki dla każdej stosowanej metody $\mathrm{R}^{2}=0,98$. Tlenki $\mathrm{Al}_{2} \mathrm{O}_{3}$ i $\mathrm{K}_{2} \mathrm{O}$ wchodzące w skład chemiczny minerałów ilastych również wykazały wysoki współczynnik determinacji. Potas w każdym przypadku osiągnął R2 na poziomie 0,98 , natomiast glin dla próbek sproszkowanych 0,88 . Sprasowanie próbek i ponowne pomiary Tracerem i Titanem pozwoliły na uzyskanie znacznie lepszych wyników: 0,91 i 0,94 . W przypadku pomiarów w atmosferze helu współczynnik osiągnął wartość 0,93 . Najlżejsze pierwiastki spośród mierzonych, tj. magnez i sód wykazały przewagę spektrometru Tracer $5 \mathrm{~g}$ z możliwością prowadzenia pomiarów w atmosferze helu. Magnez został zarejestrowany przez spektrometr Titan, ale wyniki nie wykazały żadnej korelacji, natomiast standardowe pomiary Tracerem pozwoliły osiągnąć współczynnik determinacji na poziomie $0,51,0,67$. Zastosowanie metody z przepływem helu umożliwiło uzyskanie korelacji na poziomie 0,98 , również w przypadku sodu $R^{2}$ wyniósł 0,81 . Pomiary sodu w innych konfiguracjach nie były możliwe.

Przeprowadzone badania porównawcze wykazały znaczną poprawę w identyfikacji sodu i magnezu dzięki zastosowaniu prasy hydraulicznej i pomiarów w atmosferze helu. Dla pozostałych pierwiastków jakość wyników jest na wysokim poziomie, w każdym z analizowanych przypadków. Prasowanie próbek jstanowi dodatkowy krokw preparatyce, niemniej jednak zabieg ten ogranicza wpływ zmian gęstości oraz pozwala na uzyskanie gładkiej powierzchni, co przekłada się na poprawę jakości wyników.

Wyniki pomiarów chemicznych wykonanych aparatami przenośnymi są wykorzystywane do przygotowania modeli mineralogiczno-chemicznych. Na rysunku 4 przedstawiono wykresy korelacyjne dla głównych minerałów analizowanych skał w otworze P4. W zestawieniu uwzględniono takie minerały jak: kwarc, kalcyt, sumę minerałów ilastych (miki, illit, chloryt, kaolinit), miki + illit, anhydryt oraz hematyt; zostały one odniesione do udziałów takich pierwiastków jak: krzem $\left(\mathrm{SiO}_{2}\right)$, wapń $(\mathrm{CaO})$, potas $\left(\mathrm{K}_{2} \mathrm{O}\right)$, glin $\left(\mathrm{Al}_{2} \mathrm{O}_{3}\right)$, siarka $(\mathrm{S})$, żelazo $\left(\mathrm{Fe}_{2} \mathrm{O}_{3}\right)$. Otrzymane wykresy stosowane są do zbudowania modeli umożliwiających interpretację mineralogiczną/litologiczną na podstawie regresji liniowej lub wielowymiarowej. W zestawieniu wykorzystano dane nieskalibrowane, co umożliwiło zwrócenie uwagi na różne poziomy pomiarów chemicznych XRF. Współczynniki determinacji dla każdej metody są na wysokim poziomie, co umożliwia zbudowanie dokładnych modeli mineralogicznno-chemicznych, zarówno stosując spektrometr Titan S1, jak też Tracer 5g. 
$\mathrm{SiO}_{2}$

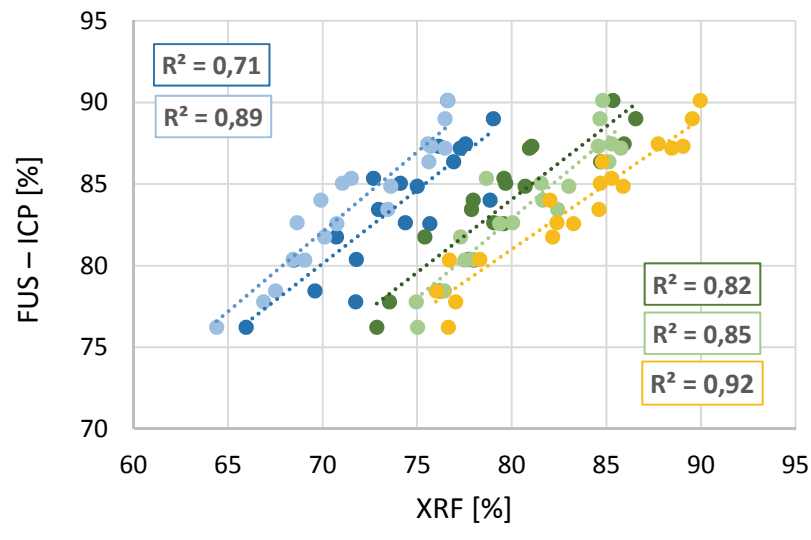

- Titan $\bullet$ Titan (prasa) $\bullet$ Tracer $\bullet$ Tracer (prasa) • Tracer He

$\mathrm{Al}_{2} \mathrm{O}_{3}$

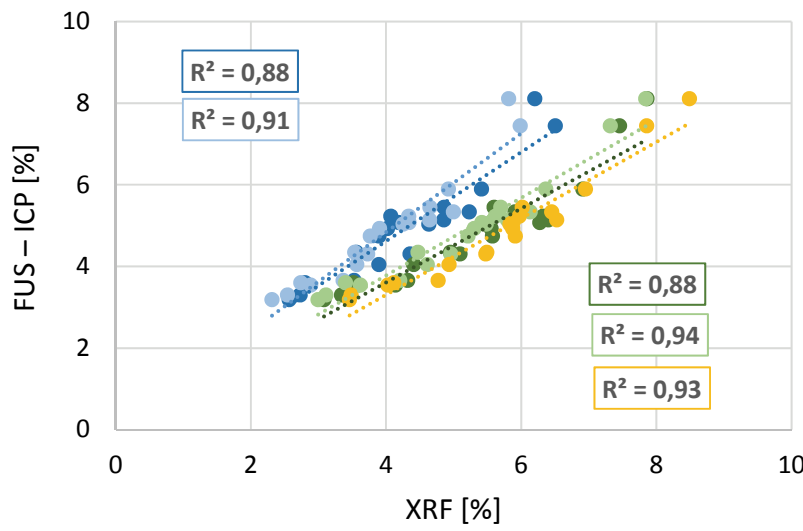

- Titan - Titan (prasa) - Tracer - Tracer (prasa) - Tracer He

MgO

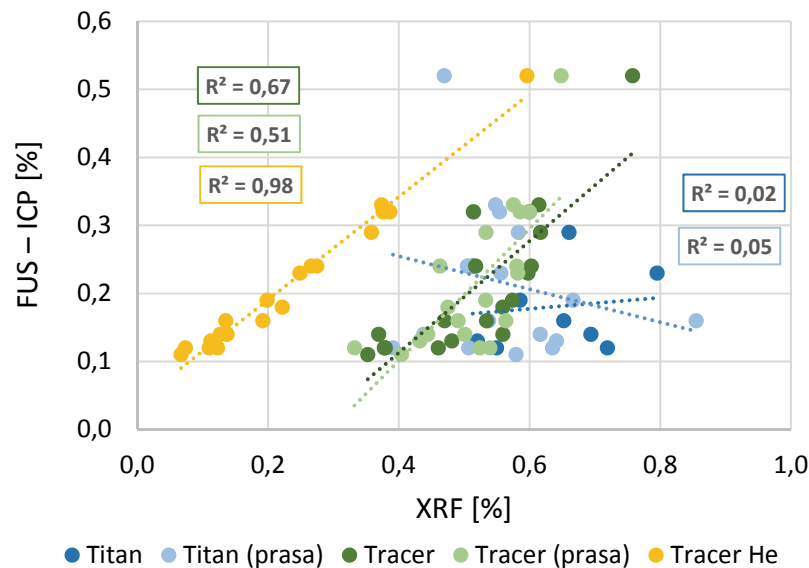

Rys. 3. Wykresy korelacyjne pomiarów chemicznych XRF wykonanych spektrometrami Titan S1 i Tracer 5g na próbkach sypkich i sprasowanych, w odniesieniu do pomiarów laboratoryjnych FUS-ICP

Fig. 3. Cross - plots of XRF chemical measurements conducted by Titan S1 and Tracer $5 \mathrm{~g}$ spectrometers on the powder samples and tablets in relation to FUS-ICP laboratory measurements

W próbkach wytypowanych do przeprowadzenia analiz w otworze P4 nie stwierdzono występowania plagioklazów oraz dolomitu. W celu przetestowania możliwości spektrometru Tracer $5 \mathrm{~g}$ do pomiaru sodu i magnezu oraz do wykonania modeli mineralogiczno-chemicznych dla tych składników

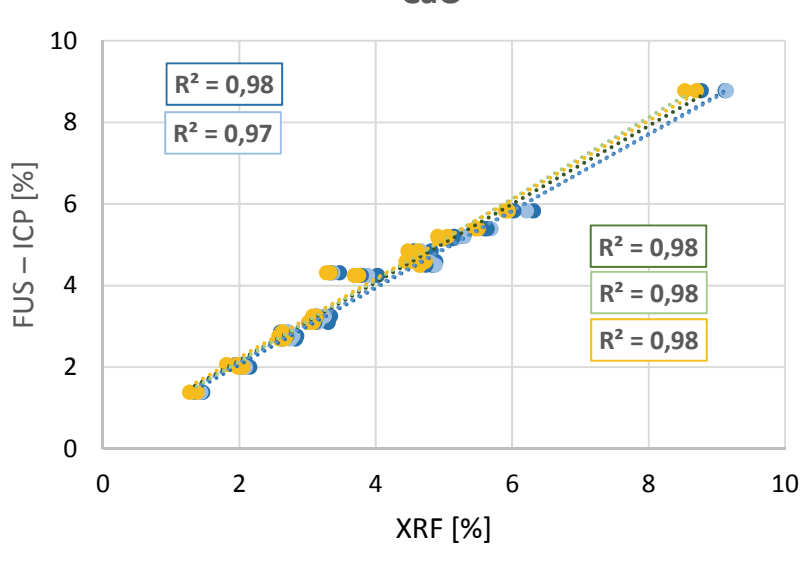

- Titan Titan (prasa) - Tracer Tracer (prasa) $\odot$ Tracer He

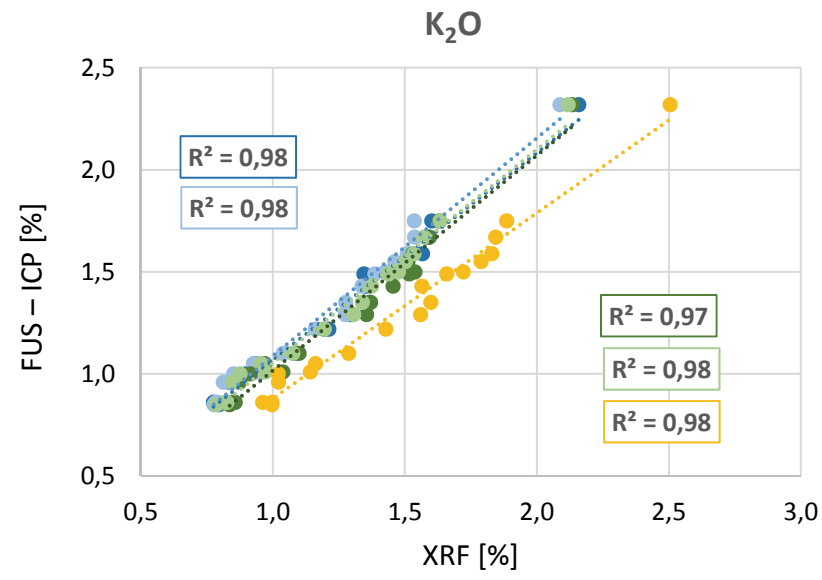

- Titan Titan (prasa) - Tracer Tracer (prasa) Tracer He

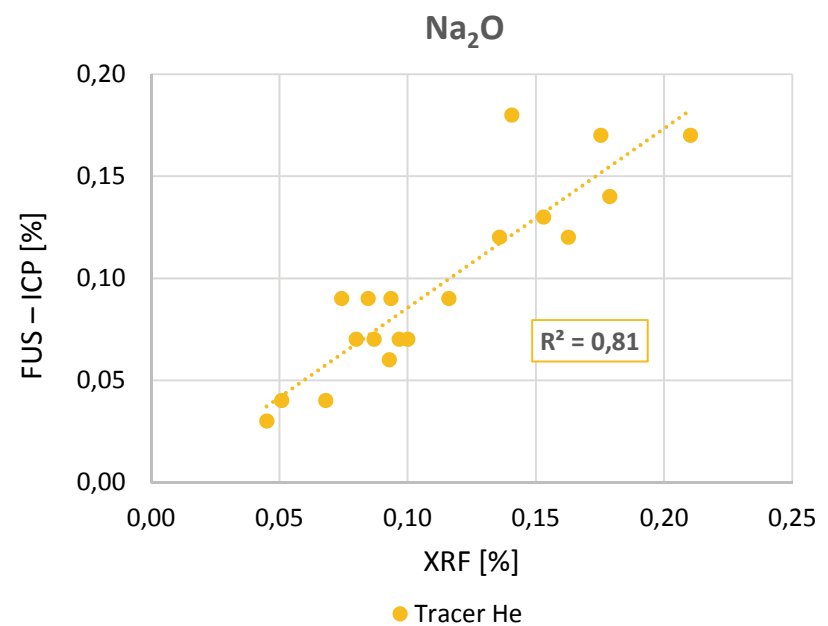

Tracer $\mathrm{He}$ wykonano serię pomiarów na 11 próbkach z otworu J1 (rys. 5). Wyniki przedstawiono w postaci wykresów korelacyjnych dla wybranych minerałów i odpowiadających im wskaźników w postaci tlenków: skalenie zestawiono $\mathrm{z} \mathrm{Na}_{2} \mathrm{O}$, dolomit z MgO, kwarc z $\mathrm{SiO}_{2}$ oraz sumę minerałów ilastych (miki, illit, 

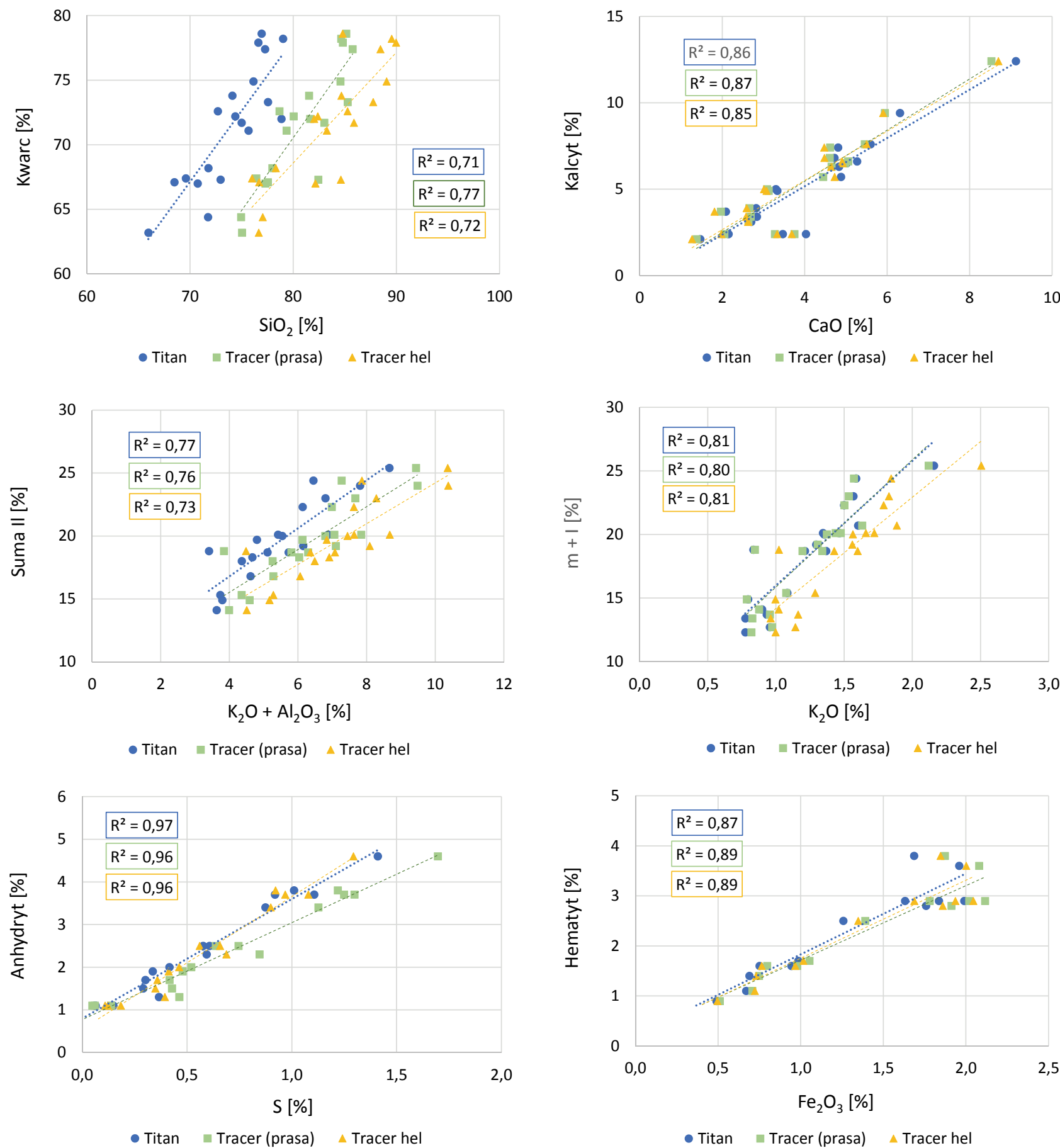

Rys. 4. Wykresy korelacyjne pomiarów chemicznych wykonanych spektrometrami Titan S1, Tracer 5g i mineralogicznych XRD, będące podstawą do tworzenia modeli mineralogiczno-chemicznych w otworze P4

Fig. 4. Cross - plots of chemical measurements conducted by Titan S1 and Tracer $5 \mathrm{~g}$ spectrometers in relation to XRD measurements, which are the basis for developing mineralogical-chemical models in the P4 well

chloryt, minerał mieszanopakietowy illit/smektyt) z $\mathrm{Al}_{2} \mathrm{O}_{3}$. Współczynnik determinacji dla sumy skaleni i tlenku sodu wynosi 0,82 , co pozwala na stworzenie modelu uwzględniającego skalenie sodowe (plagioklazy). Również w przypadku korelacji dolomitu z tlenkiem magnezu uzyskano wysoki współczynnik $R^{2}$ wynoszący 0,77 . Niestety w części próbek nie stwierdzono występowania dolomitu, $\mathrm{z}$ tego powodu wymagane jest wykonanie większej ilości badań w celu udokładnienia modelu. W zestawieniu zamieszczono również główne składniki analizowanych skał i porównano je z pomiarami wykonanymi Titanem. Model dla kwarcu jest bardziej precyzyjny niż w przypadku otworu $\mathrm{P} 4$ i w przypadku serii pomiarów wykonanych Titanem $-\mathrm{R}^{2}$ wyniosło 0,81 , natomiast dla analiz przeprowadzonym Tracerem 0,92. Suma minerałów ilastych w zestawieniu z glinem również jest na wysokim poziomie, współczynnik determinacji wynosi 0,90 i 0,87. 

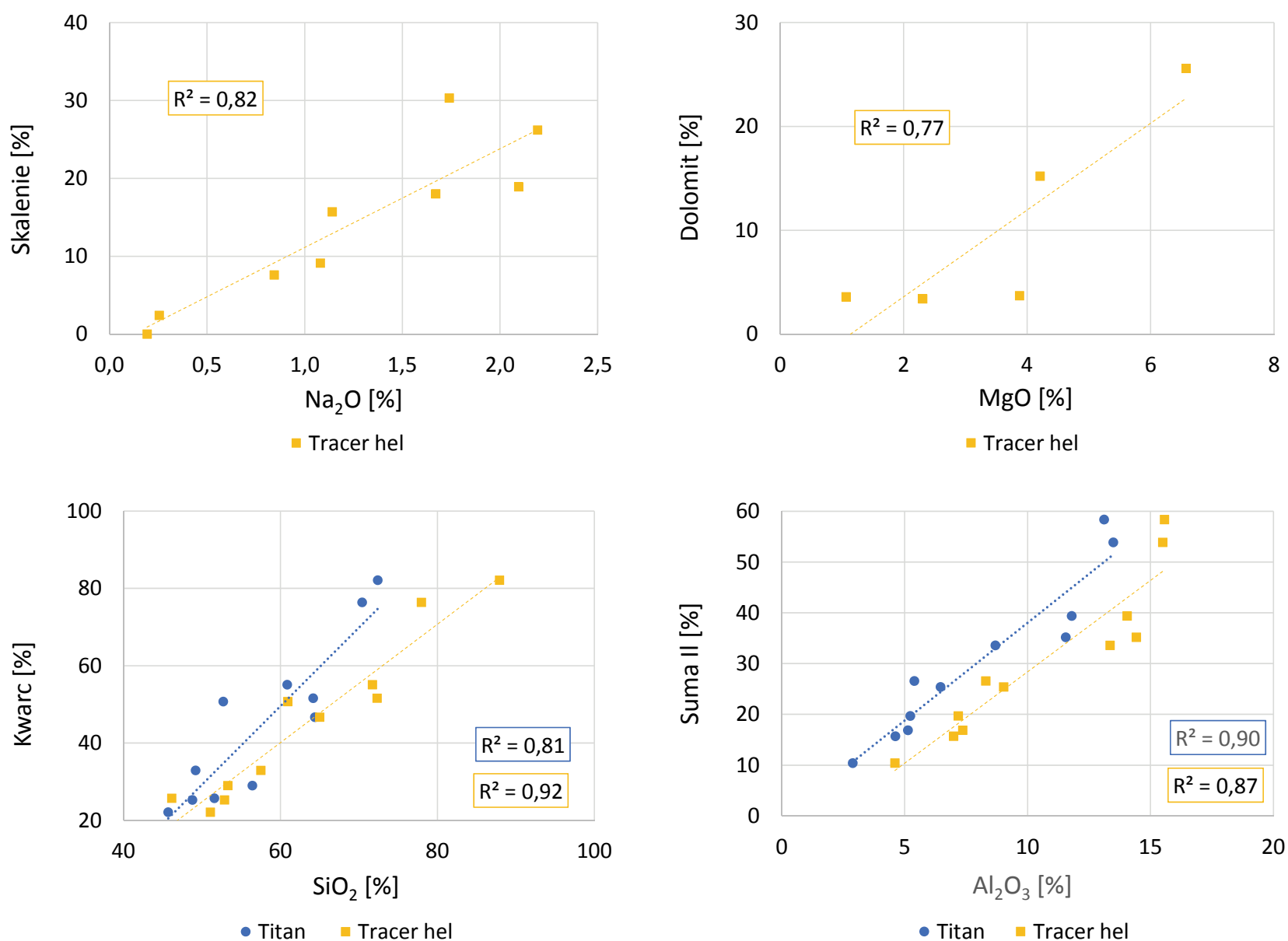

Rys. 5. Wykresy korelacyjne pomiarów chemicznych wykonanych spektrometrami Titan S1, Tracer 5g i mineralogicznych XRD, będące podstawą do tworzenia modeli mineralogiczno-chemicznych w otworze J1

Fig 5. Cross - plots of chemical measurements conducted by Titan $\mathrm{S} 1$ and Tracer $5 \mathrm{~g}$ spectrometers in relation to XRD measurements, which are the basis for developing mineralogical-chemical models in the J1 well

Dla próbek pobranych z otworu J1 wykonano również serię badań radiometrycznych $(\mathrm{K}, \mathrm{U}, \mathrm{Th}) \mathrm{z}$ zastosowaniem aparatury RT-50. Wyniki badań przedstawiono na wykresie korelacyjnym (rys. 6). Pomimo różnych metod pomiarowych i czasu analiz (XRF Tracer $=5$ min, spektrometr RT-50 = 3 h), wyniki wykazały się zadowalającymi współczynnikami determinacji. $\mathrm{R}^{2}$ dla potasu wynosi 0,98 , natomiast dla toru i uranu około 0,7 . W części próbek zawartość uranu była poniżej limitu detekcji stąd badania uranu wymagają przeprowadzenia analiz na większej liczbie próbek. W przypadku zastosowania danych do stworzenia spektrometrycznego profilowania gamma (GR), możliwe jest pominięcie uranu, czego wynikiem będzie krzywa bezuranowa (GR_KT). Spektrometr Titan cechuje się znacznie wyższymi limitami detekcji dla uranu oraz toru, z tego powodu nie pozwolił on na określenie zawartości wymienionych pierwiastków w analizowanych skałach.

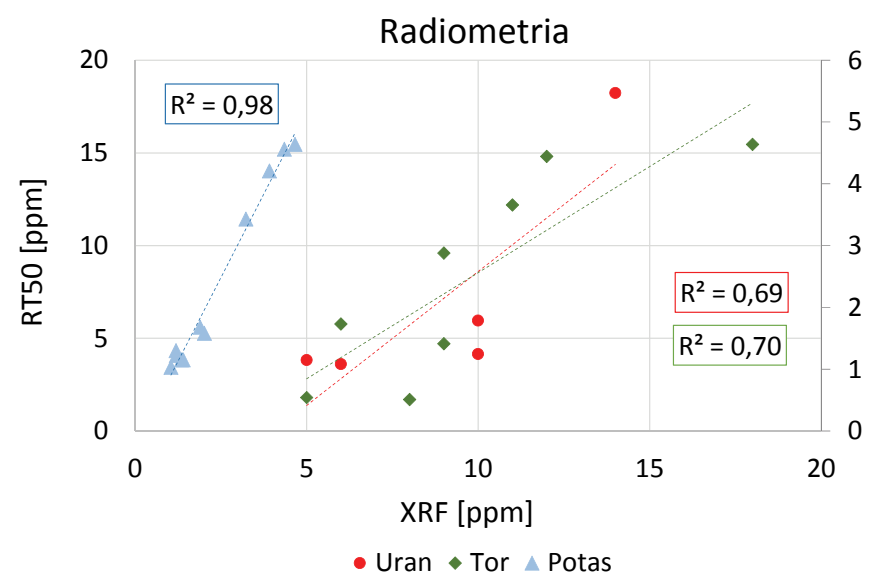

Rys. 6. Wykresy korelacyjne pomiarów potasu (K), uranu (U) oraz toru (Th) wykonanych spektrometrem Tracer $5 \mathrm{~g}$ i RT-50, w otworze $\mathrm{J} 1$

Fig. 6. Cross - plots of potassium (K), uranium (U) and thorium $(\mathrm{Th})$ measurements conducted by Tracer $5 \mathrm{~g}$ and RT-50 spectrometers in the $\mathrm{J} 1$ well 


\section{Wnioski}

Badania z wykorzystaniem przenośnych spektrometrów fluorescencji rentgenowskiej XRF umożliwiają precyzyjne określanie składu chemicznego skał. W pracy przedstawiono wyniki badań próbek skał z otworów P4 i J1 wykonane aparatem Tracer $5 \mathrm{~g}$, pozwalającym na wykonywanie pomiarów w atmosferze helu. Wyniki te zostały przedstawione na tle analiz przeprowadzonych dotychczas stosowanym spektrometrem Titan S1 oraz na tle badań laboratoryjnych (chemicznych, radiometrycznych oraz mineralogicznych).

Metodyka przygotowywania próbek uwzględniająca prasowanie zmielonych skał, umożliwia wykonywanie pomiarów w atmosferze helu oraz poprawia jakość wyników dla pierwiastków lekkich, również w przypadku stosowania spektrometru Titan.

Badania prowadzone z zastosowaniem helu wykazały możliwość detekcji tlenku sodu $\left(\mathrm{Na}_{2} \mathrm{O}\right)$ oraz znaczną poprawę w analizach zawartości magnezu, toru i uranu. W przebadanych skałach uran oraz tor występowały w zbyt małych ilościach, aby mogły zostać zarejestrowane przez spektrometr Titan. Zawartość tlenku magnezu mieściła się w granicach od 0,1 do $0,5 \%$ (według FUS-ICP), co również jest zbyt małą ilością dla uzyskania zadowalających wyników w przypadku Titana. Metoda wykorzystująca przepływ helu umożliwiła oznaczenie dodatkowych pierwiastków i na ich podstawie zbudowanie modeli mineralogiczno-chemicznych uwzględniających dolomit, skalenie sodowe oraz wykonanie profilowania gamma.

Artykuł powstał na podstawie pracy statutowej pt.: Zastosowanie przenośnego spektrometru XRF do pomiarów rdzeni wiertniczych $w$ atmosferze helu - praca INiG - PIB na zlecenie MNiSW; nr zlecenia: 0028/SW/2020, nr archiwalny: DK-4100-0016/2020.

\section{Literatura}

Acquafredda P., 2019. XRF Technique. Physical Sciences Reviews. Alnahwi A., Loucks R.G., 2019. Mineralogical composition and total organic carbon quantification using $\mathrm{x}$-ray fluorescence data from the Upper Cretaceous Eagle Ford Group in southern Texas. $A A P G$ Bulletin, 103(12): 2891-2907. DOI: 10.1306/04151918090.

Bruker Corporation, www.bruker.com (dostęp: wrzesień 2019).

Chao Y., Cancan Z., Feng Z., Song., Chaliu Li., 2015. A novel method for quantitative geosteering using azimuthal gamma-ray log. Applied Radiation and Isotopes, 96: 63-70. DOI: 10.1016/j. apradiso.2014.11.015

Chen J.J., Shugar A., Jehle A., 2018. X-radiography of cultural heritage materials using handheld XRF spectrometers. Wiley: 1-8. DOI: $10.1002 / x r s .2947$

Conrey R.M., Goodman E.M., Bettencourt N., Seyfarth A., Van Hoose A., Wolff J.A., 2014. Calibration of a portable X-ray fluorescence spectrometer in the analysis of archaeological samples using influence coefficients. Geochemistry Exploration Environment Analysis, 14(3): 291-301. DOI: 10.1144/geochem2013-198.

Jarvie D., Hill M.R.J., Ruble T.E., Pollastro R.M., 2007. Unconventional shale-gas systems: The Mississippian Barnett shale of north-central Texas as one model for thermogenic shale-gas assessment. American
Association of Petroleum Geologists Bulletin, 91: 475-499. DOI: 10.1306/12190606068

Jędrychowska S., Wieczorek A., 2013. Analiza wielopierwiastkowa środków smarowych z wykorzystaniem techniki spektrometrii fluorescencji rentgenowskiej z dyspersją fali. Nafta-Gaz, 2013, 6: $476-485$.

Kowalska S., Kubik B., Skupio R., Wolański K., 2018. Rekonstrukcja profilu litologicznego na podstawie wyników pomiarów składu chemicznego rdzeni wiertniczych i próbek okruchowych. Materiaty konferencyjne Międzynarodowej Konferencji NaukowoTechnicznej Geopetrol 2018. Wyd. Instytut Nafty i Gazu - PIB, Kraków: 115-121.

Kozak M., 2010. Zastosowanie optycznej spektrometrii emisyjnej, ze wzbudzeniem w plazmie indukowanej w badaniach przetworów naftowych. Nafta-Gaz, 7: 606-612.

Loubser M., Verryn S., 2008. Combining XRF and XRD analyses and sample preparation to solve mineralogical problems. South African Journal of Geology, 111(2-3): 229-238. DOI: 10.2113/ gssajg.111.2-3.229.

Ogburn D., Sillar B., Sierra J. C., 2012. Evaluating effects of chemical weathering and surface contamination on the in situ provenance analysis of building stones in the Cuzco region of Peru with portable XRF. Journal of Archaeological Science, 40(4): 1823-1837.

Rowe H., Hughes N., Robinson K., 2012. The quantification and application of handheld energy-dispersive $\mathrm{X}$-ray fluorescence (ED-XRF) in mudrock chemostratigraphy and geochemistry. Chemical Geology, 324-325: 122-131. DOI: 10.1016/j. chemgeo.2011.12.023

Skupio R., 2014. Wykorzystanie przenośnego spektrometru XRF do pomiarów składu chemicznego skał. Nafta-Gaz, 11: 771-777.

Skupio R., 2020. Portable XRF spectrometer with helium flow as a tool for lithological interpretation. Geology, Geophysics and Environment. 46(4): 315-320.

Skupio R., Dohnalik M., 2015. Improvement spectrometric gamma measurements on shale cores with the use of the BGO scintillation detector. Nafta-Gaz, 11: 847-855. DOI: 10.18668/NG2015.11.06.

Skupio R., Wolański K., 2019. Spektrometryczne pomiary gamma rdzeni wiertniczych o niskiej aktywności. Nafta-Gaz, 6: 324-329. DOI: $10.18668 /$ NG.2019.06.03.

Skupio R. Zagórska U., Kowalska S. 2020. Kalibracja wyników analiz chemicznych piaskowców czerwonego spągowca wykonanych przenośnym spektrometrem XRF. Nafta-Gaz, 1: 12-17. DOI: 10.18668/NG.2020.01.02

Wang F.P., Gale J.F.W., 2009. Screening criteria for shale-gas systems. Gulf Coast Association of Geological Societies Transactions, 59: 779-793.

Wieczorek A., 2012. Ocena możliwości wykorzystania techniki spektrometrii rentgenowskiej z dyspersja fali do badania zawartości szkodliwych i kancerogennych metali ciężkich w produktach naftowych. Nafta-Gaz, 10: 699-707.

Yasin Q., Du Q., Sohail G.M., Ismail A., 2017. Impact of organic contents and brittleness indices to differentiate the brittle-ductile transitional zone in shale gas reservoir. Geoscience Journal, 21(5), 780-789.DOI: 10.1007/s12303-017-0007-7.

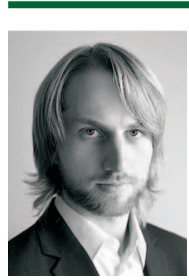

Mgr inż. Rafał SKUPIO

Asystent w Zakładzie Geofizyki Wiertnicze Instytut Nafty i Gazu - Państwowy Instytut Badawczy ul. Lubicz 25 A

31-503 Kraków

E-mail: rafal.skupio@inig.pl 